DOI 10.18699/SBB-2020-81

\title{
Сравнительный транскриптомный анализ в динамике развития протеинопатии на мышиной модели бокового амиотрофического склероза FUS(1-359)
}

\author{
Резвых А. ${ }^{1,2 *}$, Устюгов А.А. ${ }^{3}$, Морозов А.В. ${ }^{1}$, Евгеньев М.Б. ${ }^{1}$, Фуников С.Ю. ${ }^{1}$ \\ ${ }^{1}$ Институт молекулярной биологии им. Энгельгардта РАН, Москва, Россия \\ ${ }^{2}$ Московский физико-технический университет, Долгопрудныгй, Россия \\ ${ }^{3}$ Институт физиологически активных веществ РАН, Черноголовка, Россия \\ *e-mail: aprezvykh@yandex.ru
}

Ключевые слова: боковой амиотрофический склероз, протеинопатия, RNA-seq

Цель работы: Боковой амиотрофический склероз (БАС) - тяжелое нейродегенеративное заболевание, при котором происходит необратимая гибель моторных нейронов, приводящая к прогрессирующему параличу и неминуемой смерти пациента. Фокус последних исследований направлен на изучение РНК-связывающих белков, таких как FUS и TDP43, мутации в которых приводят к агрегации белков, а также нарушению РНК-метаболизма. При этом неясно, какой из данных механизмов играет первичную роль в развитии патологического процесса. Для ответа на этот вопрос, мы провели сравнительный анализ экспрессии генов в динамике развития протеинопатии у трансгенной мышиной модели FUS(1-359).

Memoдbl: Дифференциальную экспрессию и альтернативный сплайсинг анализировали при помощи секвенирования мРНК тканей спинного мозга с помощью секвенатора Illumina NextSeq 500, с последующей биоинформатической обработкой данных. Агрегацию белков выявляли с помощью метода иммуногистохимии, визуализировали методом конфокальной микроскопии, нарушение двигательной активности анализировали с использованием системы регистрации походки Noldus Catwalk XT.

Результаты: Ранние проявления протеинопатии, детектируемые в единичных нейронах у мышей в возрасте 90 дней, протекают бессимптомно и сопровождаются изменениями в альтернативном сплайсинге, заключавшимися прежде всего в удержании интронов в транскриптах мотонейронов спинного мозга. Однако уже через месяц протеинопатия лавинообразно нарастала, приводя к масштабным изменениям в транскриптомном профиле клеток спинного мозга. Данные изменения выражаются в активации провоспалительного фенотипа микроглии и нарушение функции ацетилхолиновых синапсов в мотонейронах.

$B b l в o \partial b l$ : Изменения транскриптомного профиля в тканях спинного мозга при FUS-опосредованной протеинопатии, начинающиеся на пресимптоматической стадии и приобретают лавинообразный характер уже через 1 месяц, что приводит к массивной гибели мотонейронов спинного мозга и смерти мышей. Дальнейшие исследования систем клеточной адаптации, например, убиквитинпротеасомной системы позволят расширить наши представления о БАС и изучить возможность таргетной терапии этого заболевания.

Благодарности: Работа поддержана грантом Президента РФ МК-3316.2019.4 и грантом РФФИ № 20-34-90028. 